Jurnal Indonesia Sosial Teknologi: p-ISSN: 2723 - 6609

e-ISSN : 2745-5254

Vol. 2, No. 4 April 2021

\title{
DINAMIKA TRADISI NYUMBANG PADA MASYARAKAT (STUDI KASUS: DESA PEMATANG GANJANG, SERDANG BEDAGAI)
}

\author{
Dhita Mariane Perdhani Putri Manik \\ Universitas Negeri Medan \\ Email: riane_dhita11@yahoo.com
}

\begin{abstract}
Village communities have a basic concept, namely living together with full awareness and sense of responsibility. People live in groups. Group life causes a close relationship that exists with each other, so that mutual cooperation is an obligation and a necessity for the community itself. Reciprocal factors applicable to the tradition donate still attached tothe basis of reciprocity value on different types of donations that had been done. Most of the women are actively involved in this tradition of donating. The purpose of this study was to see whether the dynamics of thetradition nyumbang occur in the community of Pematang Ganjang Village, Serdang Bedagai Regency. This research method is descriptive qualitative research. Data collection was carried out through direct observation and in-depth interviews. The results of this study can be seen that there are dynamics of thetradition nyumbang that occur in society. Initially people menyumbang money, but now there are donating goods or materials needs. As well as seeing the reason the community still maintains thetradition Nyumbang in the form of a celebration, death, or other events. This tradition is believed to be able to strengthen brotherly relations between communities and foster a form of concern for these communities. Therefore, the role of the family is very necessary in carrying out this tradition, in which the family plays an important role, so that the children or their descendants can continue to preservetradition Nyumbang this
\end{abstract}

Keyword: exchange; tradition; nyumbang

\begin{abstract}
Abstrak
Masyarakat desa memiliki konsep dasar yaitu hidup bersama yang penuh kesadaran dan rasa tanggung jawab. Orang hidup secara berkelompok. Kehidupan berkelompok menyebabkan adanya hubungan yang erat yang terjalin satu sama lain, sehingga gotong royong merupakan suatu kewajiban dan kebutuhan bagi masyarakat itu sendiri. Faktor timbal-balik yang berlaku pada tradisi nyumbang menjadi dasar masih melekatnya nilai resiprositas pada berbagai jenis sumbangan yang selama ini dilakukan. Kebanyakan perempuanlah yang turut aktif dalam tradisi sumbang menyumbang ini. Tujuan penelitian ini adalah untuk melihat adakah dinamika tradisi nyumbang yang terjadi pada masyarakat Desa Pematang Ganjang Kabupaten Serdang Bedagai. Metode penelitian ini merupakan penelitian kualitatif deskriptif. Pengumpulan data dilakukan melalui observasi langsung dan wawancara mendalam. Hasil penelitian ini dapat dilihat bahwa adanya dinamika tradisi nyumbang yang terjadi pada masyarakat. Awalnya masyarakat menyumbang
\end{abstract}


uang, namun sekarang ada yang menyumbang barang atau bahan-bahan kebutuhan. Serta melihat alasan masyarakat masih mempertahankan tradisi Nyumbang dalam bentuk acara hajatan, kematian, ataupun acara-acara lainnya. Tradisi ini diyakini dapat mempererat hubungan persaudaraan antar masyarakat dan menumbuhkan salah satu wujud kepedulian terhadap masyarakat tersebut. Oleh karena itu peran keluarga sangat diperlukan dalam melaksanakan tradisi ini, yang dimana keluarga memegang peranan penting, agar anak-anak atau keturunannya dapat terus melestarikan tradisi Nyumbang ini.

Kata kunci: pertukaran; tradisi; nyumbang

\section{Pendahuluan}

Indonesia memiliki keanekaragaman budaya yang masih terjaga. Keberagaman suku, adat istiadat dan budaya yang ada di Negara Indonesia menjadikan Indonesia kaya akan budaya nasional, terlebih lagi banyak masyarakat yang memelihara budaya yang diwariskan oleh nenek moyang pada saat ini. Budaya adalah cara hidup yang dikembangkan dan dibagikan oleh sekelompok orang dan diwariskan dari generasi ke generasi. Budaya adalah keseluruhan pengetahuan manusia sebagai makhluk sosial yang mereka gunakan untuk memahami pengalamannya dan berfungsi sebagai kerangka kerja untuk terwujudnya perilaku (Soerjono \& Sulistyowati, 2013).

Masyarakat dan budaya adalah dua hal yang tidak terpisahkan satu sama lain, karena tidak ada masyarakat tanpa budaya, begitu juga, budaya hanya ada dalam masyarakat. Linton dalam (Soerjono \& Sulistyowati, 2013) menjelaskan bahwa masyarakat merupakan kelompok manusia yang telah cukup lama hidup dan bekerja sama cukup lama sehingga mereka dapat membangun dirinya dan menganggap diri mereka sebagai suatu kesatuan sosial dengan batas-batas yang dirumuskan dengan jelas.

Masyarakat di desa mempunyai hubungan yang lebih erat dan mendalam antar sesama warganya. Sistem kehidupan biasanya berkelompok, atas dasar kekeluargaan (Setiadi, 2017). Masyarakat desa memiliki konsep dasar hidup bersama yang penuh kesadaran dan tanggung jawab. Kehidupan secara berkelompok menyebabkan terjalinnya hubungan yang semakin dekat satu dengan lainnya, sehingga sikap saling menolong merupakan sebuah keharusan dan menjadi sebuah kebutuhan. Bahkan dengan segala cara masyarakat desa akan ikut membantu ada diantara mereka yang mengalami masalah dalam hidupnya.

Tradisi adalah keseluruhan benda material dan gagasan yang berasal dari msa lalu namun benar-benar masih ada kini, belum dihancurkan, dirusak, dibuang, atau dilupakan. Tradisi hanya berarti bagian-bagian warisan sosial khusus yang memenuhi syarat saja yakni yang tetap bertahan hidup di masa kini, yang masih kuat ikatannya dengan kehidupan masa kini (Martono, 2011). Di dalam tradisi diatur bagaimana manusia berhubungan dengan manusia lain, bagaimana manusia bertindak bertindak terhadap lingkungan sekitar, dan bagaimana perilaku manusia terhadap alam yang berkembang menjadi suatu sistem yang memiliki pola dan norma dan juga ketentuan hukum dan peraturan serta penyimpangan. 
Tradisi nyumbang merupakan kebiasaan masyarakat pada pelaksanaan hajatan atau pesta untuk memberikan bantuan dan pertolongan yang didalamnya terdapat suatu keyakinan bahwa kewajiban untuk membalas balik apa yang sudah diberikan. Oleh sebab itu resiprositas (pertukaran) dapat mengatur perilaku seseorang dalam tradisi nyumbang, sehingga masyarakat yang menyumbang dan disumbang dapat menyesuaikan diri dalam norma pertukaran (Santoso, 2017).

Proses dalam penyelenggaraan hajatan, tuan rumah akan mengundang banyak orang dari berbagai lapisan mulai dari keluarga, saudara, tetangga, kerabat, teman dan orang-orang yang mereka kenal untuk menjalankan acara hajatan tersebut. Dengan mengundang banyak orang, secara otomatis maka pengeluaran untuk acara akan lebih besar tetapi disisi lain yang diperoleh juga akan semakin besar. Modal yang paling besar bagi seorang yang menggelar pesta atau hajatan adalah kemampuan untuk menarik sumbangan dari orang lain (Geertz, 2014).

Pola kehidupan masyarakat di Desa Pematang Ganjang sangat erat antara satu individu dengan individu lainnya, berbagai tradisi dan kegiatan sosial dilakukan secara bersama-sama. Salah satu kegiatan sosial yang masih dilakukan oleh masyarakat adalah kegiatan sosial yang dikenal dengan Nyumbang. Kegiatan Nyumbang merupakan bentuk kerjasama antara satu komunitas dengan komunitas lainnya.

Hal ini dilakukan karena menurut masyarakat yang ada di Desa Pematang Ganjang melihat bahwa kegiatan Nyumbang dapat membantu masyarakat ketika akan mengadakan suatu pesta dan menjadikan hubungan persaudaraan serta menumbuhkan suatu wujud kepedulian masyarakat begitu tinggi dengan sesamanya. Dari hasil observasi yang dilakukan oleh peneliti ditemukan bahwa sumbangan yang dilakukan masyarakat di Desa Pematang Ganjang terlihat dari rasa bekerja sama dan saling percaya yang terjadi diantara orang yang menyumbang dan orang yang disumbang.

Bentuk kepercayaan diartikan sebagai bentuk saling percaya antar masyarakat melalui interaksi sosial dalam melakukan Nyumbang yang didasari dengan adanya ikatan persaudaraan, saling memberi, dan atas dasar kesepakatan bersama sehingga saling menguntungkan baik dalam hal moril maupun materil. Kegiatan Nyumbang merupakan salah satu kegiatan yang paling positif dan bermanfaat bagi sesama. Kegiatan sumbang menyumbang mengandung unsur kerjasama resiprositas (hubungan timbal balik) antara masyarakat yang turut terlibat di dalam acara hajatan. Resiprositas dianggap sebagai strategi yang dilakukan masyarakat desa untuk tetap melestarikan tradisi yang dimiliki agar tetap bertahan hingga sekarang (Putri, 2012).

Dalam pertukaran sosial, menurut Homans dalam (Ritzer, 2012) menjelaskan perilaku individu-individu di dalam kelompok. Menurut Homans pola pertukaran harus dianalisis dengan mempehatikan motif individu yang terlibat dalam transaksi tersebut. Individu memberikan dan menerima memberikan atas dasar adanya kewajiban dan rasa tanggung jawab. Persembahan untuk korban apa yang telah diberikan individu lainnya. 
Dalam masyarakat tradisional dikenal pertukaran dengan sistem barter. Sementara itu, karakteristik pertukaran yang berubah dalam ekonomi tradisional dan berurusan dengan sistem pertukaran komersial memunculkan istilah timbal balik. Teori timbal balik yang pertama kali dikemukakan oleh Malinowski mengenai sistem perdagangan antara penduduk Kepulauan Trobriand atau Boyowa yang terletak di sebelah tenggara Papua Nugini. Benda yang diperdagangkan dengan cara ditukar (barter) adalah berupa berbagai macam bahan makanan, bahan kerajinan, dan alat tangkap, perkebunan, dan rumah tangga (Koentjaraningrat, 2014).

Kebiasaan saling tukar menukar ini melibatkan seluruh anggota masyarakat, dengan adanya pertukaran ini maka mereka memeroleh keuntungan. Keuntungan dari suatu pertukaran tidak selalu berupa uang, barang atau jasa, melainkan berupa kasih sayang, kehormatan, kecantikan dan komunikasi yang baik. Sehingga penelitian ini bertujuan untuk melihat ada tidaknya terjadi perubahan tradisi nyumbang pada masyarakat serta melihat cara masyarakat dalam mempertahankan tradisi yang diturunkan ke generasi selanjutnya. Agar hubungan yang terjalin selama ini tetap baik dan rasa saling menghormati semakin kuat.

Sebuah tindakan pertukaran tidak akan terjadi apabila dari pihak-pihak yang terlibat ada yang tidak mendapatkan keuntungan dari suatu transaksi pertukaran. Tidak mungkin suatu pertukaran sosial terjadi kalau satu pihak saja mendapatkan keuntungan, sedangkan yang lain tidak mendapatkan apa-apa. Hubungan yang terjalin saat ini tidak mungkin terjadi kalau ada pihak yang tidak memperoleh keuntungan (Damsar, 2011).

\section{Metode Penelitian}

Penelitian ini menggunakan penelitian kualitatif dengan menggunakan pendekatan etnografi. Penelitian kualitatif adalah prosedur penelitian yang menghasilkan data deskriptif berupa kata-kata tertulis ataupun lisan dari orang-orang dan berperilaku yang dapat diamati dan diarahkan pada latar individu secara utuh. Penelitian kualitatif dipilih karena penelitian ini berguna untuk mengungkap proses peristiwa secara mendetail, sehingga diketahui dinamika suatu realitas sosial dan pengaruh timbal balik dari realitas sosial (Afrizal, 2015).

Pendekatan etnografi merupakan prosedur penelitian kualitatif untuk menggambarkan, menganalisa dan menafsirkan unsur-unsur dari sebuah keompok budaya seperti pola perilaku, kepercayaan, dan bahasa yang berkembang dari waktu ke waktu (Fitrah, 2018). Penelitian ini diarahkan untuk meneliti kenyataan dilapangan yang berkaitan dengan dinamika tradisi nyumbang yang terjadi pada masyarakat Desa Pematang Ganjang, Serdang Bedagai agar memperoleh data deskriptif berupa kata-kata tertulis yang didapat dari sumber data primer melalui proses wawancara dan masyarakat yang terlibat dalam tradisi nyumbang. Data sekunder diperoleh melalui studi kepustakaan yang terdiri dari referensi mengenai, pertukaran, masyarakat desa, kebudayaan, tradisi masyarakat, dan tradisi nyumbang.

Pengumpulan data dilakukan dengan observasi partisipan dan wawancara mendalam dengan informan yang mengetahui makna dan cara memelihara tradisi 
Nyumbang. Setelah data terkumpul dari observasi di lapangan, teknik analisis data dilakukan dengan membuat catatan etnografi, melakukan analisis wawancara etnografi, dan penulisan etnografi (Moleong, 2016).

\section{Hasil dan Pembahasan}

Mempertahankan tradisi Nyumbang pada masyarakat di Desa Pematang Ganjang, Serdang Bedagai merupakan salah satu cara agar tradisi Nyumbang tidak hilang atau tergeser oleh perkembangan jaman. Tradisi Nyumbang merupakan bentuk kerjasama antara satu komunitas dengan komunitas lainnya. Nyumbang adalah kegiatan yang dilakukan oleh masyarakat secara sadar dengan memberikan bantuan berupa uang, barang atau tenaga yang kemudian dapat dilakukan pertukaran kepada orang yang disumbang dan orang yang menyumbang dan diberikan ketika salah satunya akan mengadakan pesta atau acara secara bergilir. Kegiatan ini dilakukan dengan mengedepankan kesadaran sosial masyarakat di desa dan bertujuan untuk menjaga hubungan persaudaraan.

Tradisi Nyumbang di Desa Pematang Ganjang, Serdang Bedagai dilakukan ketika salah satu dari mereka akan mengadakan acara, baik acara pernikahan, acara khitanan, acara kematian dan lain-lain. Hal ini dilakukan karena kegiatan Nyumbang dapat membantu masyarakat saat akan mengadakan acara sehingga dapat menjalin silaturahmi yang lebih erat dan menumbuhkan wujud kepedulian yang tinggi antar sesama. Tradisi Nyumbang di Desa Pematang Ganjang Serdang Bedagai terlihat dari tingginya rasa kerjasama dan rasa saling percaya antara orang yang menyumbang dengan orang yang sedang disumbang. Bentuk kepercayaan diartikan sebagai bentuk rasa saling percaya antar masyarakat melalui interaksi sosial dalam melaksanakan kegiatan yang dilandasi oleh adanya ikatan persaudaraan, saling memberi, dan atas dasar kesepakatan bersama sehingga saling menguntungkan baik dalam hal moral dan material.

Nilai dan makna dari kegiatan Nyumbang adalah dimana terdapat rasa persatuan, senasib-sepenanggungan, pertolongan, dan gotong royong yang mereka junjung tinggi dan tetap mereka jalankan. Tradisi Nyumbang merupakan salah satu tradisi lama masyarakat Jawa yang masih diterapkan hingga saat ini. Nyumbang dilakukan pada saat acara perkawinan, khitanan atau puputan (penambalan nama anak yang baru lahir). Jika penyumbang memberikan barang belanjaan, maka orang yang disumbang wajib mengembalikan atau mengembalikan barang belanjaan sesuai dengan nilai nominal atau beratnya kepada penyumbang saat si penyumbang akan mengadakan pesta juga.

Namun, jika penyumbang belum mengadakan acara, maka itu menjadi hutang bagi yang menerima sumbangan, penyumbang dan penerima sumbangan diharuskan memiliki catatan (buku) yang berisi barang-barang tertulis tentang bahan makanan atau uang yang telah disumbangkan dan yang belum dikembalikan. Tidak hanya sembako tapi ada juga yang berbentuk sumbangan uang maupun tenaga. 
Apabila tradisi Nyumbang ini dilaksanakan oleh masyarakat dan ternyata salah satu dari mereka telah meninggal dunia dan meninggalkan hutang, maka anak atau ahli warisnya wajib untuk melanjutkan sumbangan orang tuanya. Hal inilah yang menjadikan tradisi Nyumbang dapat diwariskan secara turun-temurun dan masih dilakukan hingga saat ini oleh masyarakat Desa Pematang Ganjang, Serdang Bedagai. Disinilah peran orang tua atau keluarga yang mengajarkan atau menanamkan pemahaman pada anak-anaknya untuk melanjutkan tradisi tersebut guna menjaga silaturahmi persaudaraan yang telah dibina selama ini. Sejak kecil anak-anak telah mengenal dan melihat tradisi Nyumbang sehingga memiliki rasa tanggung jawab untuk melanjutkan tradisi Nyumbang. Inti dari tetap mempertahankan tradisi Nyumbang ini adalah rasa saling percaya.

Terbentuknya rasa saling percaya satu sama lain terjalin karena adanya ikatan saudara dan ikatan antar masyarakat desa yang terbentuk karena adanya interaksi sosial diantara mereka. Adanya tradisi ulem-ulem (memberi secara lisan) yang dilakukan ketika berpesta dapat menciptakan kesepakatan bersama dalam hal pemberian bantuan. Selain itu rasa saling percaya juga tumbuh karena pentingnya perasaan orang lain, sifat harmonis dan saling berkomunikasi dalam melaksanakan setiap kegiatan asokan yang dilakukan secara bersama, serta adanya rasa saling menghargai dan jujur dalam melaksanakan kegiatan asokan.

Sumbangan bagi yang menerima atau yang menggelar acara memberikan pemahaman bahwa orang yang Nyumbang menunjukkan bahwa dia memiliki nilai kerukunan yang baik dan hubungan sosial yang terbina antar sesama masyarakat tetap terjalin baik. Sumbangan dapat menjadi tandaa bahwa individu itu mempunyai nilai kerukunan yang baik dan hubungan yang harmonis dalam menjalankan kehidupan antar sesama masyarakat. Sehingga masyarakat yang masih menjalankan tradisi Nyumbang memiliki rasa kekeluargaan yang kuat dan solidaritas yang kuat antar sesama masyarakat. Nyumbang yang dimaknai sebagai bentuk keinginan untuk membantu sesama tidak dianggap sebagai hal yang mempengaruhi hubungan sosial antar sesama. Karena Nyumbang itu adalah bentuk keikhlasan hati kita dalam memberikan sesuatu barang atau uang yang tidak dibebankan besaran nominalnya dengan keinginan untuk membantu sesama saudara.

Tradisi Nyumbang dalam acara-acara hajatan di masyarakat Desa Pematang Ganjang merupakan suatu kewajiban yang harus dilakukan dan sebagai upaya untuk mempertahankan budaya yang telah turun menurun dilakukan dalam masyarakat. Kegiatan Nyumbang sudah menjadi kebiasaan dan sudah menjadi kewajiban jika seseorang tersebut mendapatkan undangan. Karena kewajiban itu terkadang masyarakat rela melakukan apapun untuk menyumbang sekalipun mereka berada dalam kondisi ekonomi yang sedang lemah. Karena mereka memiliki kewajiban untuk membayarkan kembali apa yang sudah disumbangkan oleh seseorang itu. 
Dinamika Tradisi Nyumbang pada Masyarakat (Studi Kasus: Desa Pematang Ganjang,

Serdang Bedagai)

\section{Kesimpulan}

Tradisi Nyumbang yang dilakukan oleh masyarakat di Desa Pematang Ganjang, Serdang Bedagai. Diartikan sebagai kegiatan yang dilakukan oleh masyarakat secara sadar dengan memberikan bantuan berupa uang, barang atau tenaga yang kemudian dapat dilakukan pertukaran kepada orang yang disumbang dan orang yang menyumbang dan diberikan ketika salah satunya akan mengadakan pesta atau acara secara bergilir. Kegiatan ini dilakukan dengan mengedepankan kesadaran sosial masyarakat di desa dan bertujuan untuk menjaga hubungan persaudaraan. Tradisi Nyumbang ini biasa dilakukan masyarakat di Desa Pematang Ganjang, Serdang Bedagai saat mempersiapkan acara, baik itu pernikahan, sunatan, penabalan nama atau kematian. Diperlukan peran orang tua atau keluarga dalam mengajarkan atau menanamkan pemahaman pada anakanaknya untuk melanjutkan tradisi tersebut guna menjaga silaturahmi persaudaraan yang telah dibina selama ini. Sejak kecil anak-anak sudah mengenal dan melihat tradisi Nyumbang ini sehingga mereka memiliki rasa tanggung jawab untuk melanjutkan tradisi ini. Oleh karena itu, di beberapa keluarga ada yang mempraktikkan kegiatan ini bersama-sama, ibu menyumbang dan anak juga menyumbang juga. Disini kita bisa melihat peran keluarga dalam menanamkan nilai-nilai budaya pada anak-anaknya. Inti dari menjaga tradisi Nyumbang adalah rasa saling percaya agar tercipta hubungan kekeluargaan yang lebih erat. 


\section{Bibliography}

Afrizal. (2008). Pengantar Metode Penelitian Kualitatif dari pengertian sampai penulisan laporan. Laboratorium Sosiologi FISIP Unand.

Damsar, D. (2011). Pengantar Sosiologi Pendidikan. Jakarta, Kencana.

Fitrah, M. (2018). Metodologi penelitian: penelitian kualitatif, tindakan kelas \& studi kasus. CV Jejak (Jejak Publisher).

Geertz, C. (2014). Agama Jawa: Abangan. Santri, Priyayi Dalam Kebudayaan Jawa, Komunitas Bambu, Depok Indonesia.

Koentjaraningrat, K. (2014). Antropologi Hukum. Antropologi Indonesia.

Martono, N. (2011). Sosiologi perubahan sosial. Jakarta: Raja Grafindo Persada.

Moleong, L. J. (2010). Methodology of Qualitative Research. Bandung: Remaja Rosda Karya.

Putri, S. N. (2012). Resiprositas Tradisi Nyumbang (Kajian Antropologi Tentang Strategi Mempertahankan Eksistensi Tradisi Nyumbang Hajatan Pada Masyarakat Jawa Di Desa Rawang Pasar IV, Kecamatan Rawang Panca Arga, Kabupaten Asahan. In FISIP USU.

Ritzer, G. (2012). Teori Sosiologi: Dari sosiologi klasik sampai perkembangan terakhir postmodern. Yogyakarta: Pustaka Pelajar, 11, 25.

Santoso, F. S. (2017). Pola Pengaturan Transaksi Sumbangan (Buwuh) Dalam Adat Perkawinan Di Desa Mayong Lor, Kecamatan Mayong, Kabupaten Jepara. Universitas Negeri Semarang.

Setiadi, E. M. (2017). Ilmu sosial \& budaya dasar. Kencana.

Soerjono, S., \& Sulistyowati, B. (2013). Sosiologi sebagai suatu pengantar. PT RajaGrafindo Persada: Jakarta. 